Article

\title{
The Use of Selective Laser Melting to Increase the Performance of $\mathrm{AlSi}_{9} \mathrm{Cu}_{3} \mathrm{Fe}$ Alloy
}

\author{
Michaela Fousova ${ }^{1,2, *}$, Drahomir Dvorsky ${ }^{1,2}$, Marek Vronka ${ }^{2}$, Dalibor Vojtech ${ }^{1}$ \\ and Pavel Lejcek ${ }^{2}$ \\ 1 Department of Metals and Corrosion Engineering, University of Chemistry and Technology Prague, \\ Technicka 5, 16628 Prague 6, Czech Republic; dvorskyd@vscht.cz (D.D.); vojtechd@vscht.cz (D.V.) \\ 2 Institute of Physics, Academy of Sciences of the Czech Republic (AS CR), Na Slovance 1999/2, \\ 18221 Prague 8, Czech Republic; vronka@fzu.cz (M.V.); lejcekp@fzu.cz (P.L.) \\ * Correspondence: fousovam@vscht.cz; Tel.: +42-022-044-4441
}

Received: 13 August 2018; Accepted: 8 October 2018; Published: 9 October 2018

\begin{abstract}
For the first time, the comprehensive characterization of the additively manufactured $\mathrm{AlSi}_{9} \mathrm{Cu}_{3} \mathrm{Fe}$ alloy is reported in this paper. Conventionally, the $\mathrm{AlSi}_{9} \mathrm{Cu}_{3}(\mathrm{Fe})$ alloy is prepared by high-pressure die casting (HPDC), but this technology largely does not offer such opportunities as additive manufacturing (AM) does, especially in the design of new lightweight parts. In the present paper, testing samples were prepared by selective laser melting (SLM), one of the AM technologies, and characterized in terms of their microstructure (by means of light microscopy, scanning electron microscopy and transmission electron microscopy in combination with analytical techniques for evaluation of chemical and phase composition) and mechanical properties (static tension, compression, and hardness). All the characteristics were compared with the HPDC reference material. Our study showed an excellent improvement both in strength (374 $\pm 11 \mathrm{MPa}$ compared to $257 \pm 17 \mathrm{MPa})$ and plasticity $(1.9 \pm 0.2 \%$ compared to $1.2 \pm 0.5 \%)$ of the material thanks to its very fine and distinctive microstructure.
\end{abstract}

Keywords: aluminum alloy; $\mathrm{AlSi}_{9} \mathrm{Cu}_{3}(\mathrm{Fe})$; selective laser melting; additive manufacturing

\section{Introduction}

In the last decades, the industry looks for new, sophisticated technologies with the intention of making technological progress, but also reducing production costs. As the environmental protection aspect is very strong in this age, it also represents one of the driving forces of the research and development. Especially in the aerospace and automotive industries, all these requirements have led to the development of lightweight materials and structures. With reduced weight, not only material costs are saved, but it also lowers the weight of the resultant means of transport associated with lower fuel consumption, as well as lower emissions of harmful exhaust gases (especially $\mathrm{CO}_{2}$ ) [1]. However, traditional manufacturing processes, such as casting, forging, extrusion, or powder metallurgy, are not able to satisfy the current trend in manufacture, which aims at new customized products of high quality, acceptable cost, repeatability and reliability, and their quick delivery to customers. Conversely, they require specific tooling, consist of multiple steps and often have to be followed by post-fabrication machining, which increases both costs and production time [2]. A new technological approach is thus needed.

Aluminum and its alloys find their application thanks to their excellent strength to weight ratio and corrosion resistance (compared to steels). The most wide-spread aluminum alloys are based on the binary Al-Si system, which provides great castability, and thus an easy production way. Elements like $\mathrm{Mg}$ or $\mathrm{Cu}$ are often added to enhance mechanical properties after an appropriate heat treatment [1]. 
$\mathrm{AlSi}_{9} \mathrm{Cu}_{3}(\mathrm{Fe})$ alloy is used especially in the automotive industry. Thanks to a relatively high content of copper, it exhibits higher mechanical strength (when 3 wt.\% of Si in AlSi12 are substituted by copper, the contribution to tensile strength is $90 \mathrm{MPa}$ [3]), but decreased corrosion resistance. It is usually processed by pressure die casting and is easy to machine. It has a low tendency towards surface defects and internal voids during solidification. Particularly, it is used for the production of thin-walled products subjected to dynamic loading, cylinder heads, and other parts of engines or various machines [4]. Mechanical properties can be significantly influenced by the control of microstructural parameters, such as the distance between dendritic arms, grain size, shape, and distribution of the eutectics, volume fraction, size, and morphology of intermetallic phases [5].

High-pressure die casting (HPDC) enables high production volumes of parts showing high surface quality. Compared to gravity casting, even more complex shapes are possible to be produced, but still, the current demands for porous structures or very small dimensions are hardly attainable. Additionally, the HPDC process is limited by the formation of defects, such as oxide films, shrinkage cavities, air porosity, etc., which cannot be eliminated. Such defects then weaken the castings structurally and exclude them for use in the field of safety applications [5].

The opportunity to satisfy industrial producers and their customers, and avoid limitations of conventional technologies is provided by additive manufacturing (AM), popularly called 3D printing. AM covers all computer-controlled processes that create three-dimensional (3D) parts by sequentially joining thin layers of materials. This unique feature makes it possible to produce complex parts directly in the desired form, without the need for expensive tools or molds, the use of which is necessary in conventional subtraction technologies. The additive approach also brings minimal material losses. An added value is a customized production. Components can be tailored according to the specific requirements of each customer. For these reasons, 3D printing is now widely considered for the production of high-performance components for aerospace, medical, power, and automotive applications [6-8].

In the AM of metals, the most available technologies are selective laser melting (SLM) and electron beam melting (EBM). They belong into the group of so-called powder-bed AM technologies. They are based on the selective melting of an input powder material that is deposited onto the working plate in successive steps so that thin layers are formed. While SLM uses a laser beam to melt the powder, a focused beam of electrons serves as the heat source in EBM $[9,10]$.

Currently, 3D printing is applied for a wide range of metallic materials, including steels, Ti and its alloys, $\mathrm{Ni}$ or Co superalloys, and copper [11]. Additionally, some aluminum powders have been successfully processed, with AlSi10Mg alloy being one of the most studied [12]. Other studies have focused on different Al-Si alloys, e.g., A356 [13], A357 [14], AlSi12(Mg) [15,16], Al-20Si [17], and Al-50Si [18]. Wrought alloys of 2xxx, 6xxx, and 7xxx classes, usually heat-treatable (EN 7075 [19], Al-Mg-Sc-Zr [20], AA-2024 [21]), have been processed as well. An interesting paper was also published on the topic of SLM applied for processing of an Al-Fe-V-Si alloy which gets very close to titanium in its strength. While a complicated preparation and high costs had hindered the development of such alloys, SLM brought promising options [22]. Similarly, SLM enabled the preparation of a high-strength thermally stable A185Nd8Ni5Co2 alloy with a composite-like microstructure containing submicrometer-sized intermetallic phases dispersed in the aluminum matrix [23]. While most of the materials for AM are based on conventional compositions, there are already some works tailoring materials specifically for AM [24,25].

Surprisingly, to the best of our knowledge, no references to the $\mathrm{AM}$ of the $\mathrm{AlSi}_{9} \mathrm{Cu}_{3}(\mathrm{Fe})$ alloy have appeared in the literature yet. As the high amount of copper in combination with high cooling rates during the AM process could yield in interesting properties (e.g., absence of intermetallic phases enhancing plasticity, high oversaturation of solid solution, and promoted strengthening), the aim of our study was to prepare this alloy by means of SLM and characterize its microstructure and mechanical performance. Therefore, in the present paper, we bring a comprehensive study in which the SLM $\mathrm{AlSi}_{9} \mathrm{Cu}_{3} \mathrm{Fe}$ alloy is compared to the same alloy, but prepared by conventional HPDC. 


\section{Materials and Methods}

The tested material was the $\mathrm{AlSi}_{9} \mathrm{Cu}_{3} \mathrm{Fe}$ alloy of a specific composition given in Table 1. A gas-atomized powder of the alloy (LPW, mass median diameter $=40 \mu \mathrm{m}$ ) was used for the purpose of additive manufacture by the selective laser melting technology (SLM). SLM Solution 280HL machine equipped with $400 \mathrm{~W}$ YLR-Faser-Laser was used. The process parameters applied for the sample production are listed in Table 2. The laser melting was carried out under a protective argon atmosphere to prevent oxidation. Dog-bone-shaped samples intended for tensile testing (Figure 1) were prepared directly, with their longitudinal axes parallel to the building direction. Sand-blasting followed the additive manufacture to remove powder particles attached to the final sample surface.

Table 1. Chemical composition (wt.\%) of the $\mathrm{AlSi}_{9} \mathrm{Cu}_{3} \mathrm{Fe}$ alloy.

\begin{tabular}{cccccccccc}
\hline & Al & Si & Cu & Fe & Mg & Zn & Mn & Ti & Sn \\
\hline SLM & bal. & 8.9 & 3.1 & 1.2 & 0.3 & 0.01 & $/$ & $/$ & $/$ \\
HPDC & bal. & 8.6 & 2.6 & 0.7 & 0.2 & 0.9 & 0.3 & 0.04 & 0.07 \\
CSN EN ISO & bal. & $8.0-11.0$ & $2.0-3.5$ & max. 1.0 & $0.1-0.5$ & max. 1.2 & $0.1-0.5$ & max. 0.15 & max. 0.1 \\
42 4339 standard & & & & & & & & &
\end{tabular}

Table 2. Parameters of the SLM process (P-power, v-scanning velocity, $\mathrm{h}$-hatching distance, $\mathrm{t}$-layer thickness).

\begin{tabular}{ccccc}
\hline $\mathbf{P}(\mathbf{W})$ & $\mathbf{V}(\mathbf{m m} / \mathbf{s})$ & $\mathbf{H}(\boldsymbol{\mu m})$ & $\mathbf{T}(\boldsymbol{\mu m})$ & Scanning Strategy \\
\hline 400 & 1300 & 150 & 50 & chess board \\
\hline
\end{tabular}

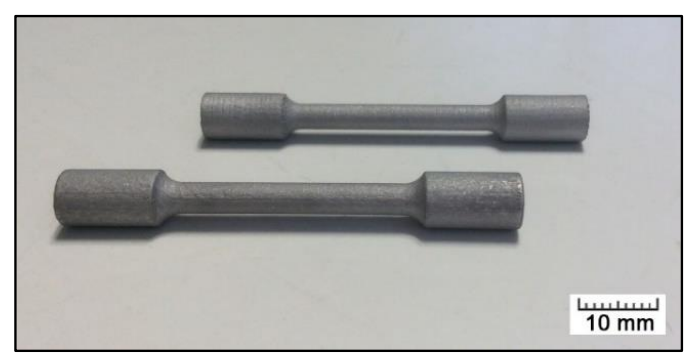

Figure 1. Tensile test samples prepared by SLM.

For a comparison between SLM and conventional manufacture, castings produced by HPDC were provided by a commercial supplier. Samples for determination of mechanical properties and structural analysis were cut out of the castings.

For the microstructure observation of the studied alloy, metallographic sections were prepared in a standard metallographic way. For the SLM samples, both transversal and longitudinal sections were prepared because of additive manufacture directionality. Therefore, the longitudinal sections represented the microstructure in the building direction, while the transversal ones in the direction perpendicular to the building direction. First, porosity was evaluated using unetched samples. The average porosity was determined by an image analysis (ImageJ software) of about 30 images captured by a light metallographic microscope (OLYMPUS PME3) across the entire longitudinal section. To reveal the microstructure, the samples were etched in $0.5 \%$ HF. Microstructures were studied by light microscope and also by a TESCAN VEGA-3 LMU scanning electron microscope (SEM) equipped with an EBSD (electron backscatter diffraction; Oxford Instruments, Aztec) analyzer. The EBSD analysis was performed with a step of $0.3 \mu \mathrm{m}$. Data were processed by Channel 5 software. Transmission electron microscopy (TEM) was used to observe nano-sized microstructural features. TEM samples were prepared perpendicular to the building direction of SLM. $1 \mathrm{~mm}$ thick plates were cut and reduced by grinding to a thickness of $100 \mu \mathrm{m}$. Subsequently, disks of $3 \mathrm{~mm}$ in diameter were punched. The final thickness in the central part of the disks was achieved by double jet electropolishing in a $30 \%$ solution 
of $\mathrm{HNO}_{3}$ in methyl alcohol at $253 \mathrm{~K}$. The conventional TEM observations were carried out by Fei Tecnai F20 field emission gun transmission electron microscope operated at $200 \mathrm{kV}$ equipped with EDS detector. EDS analysis was performed in the STEM mode with a step size of $1 \mathrm{~nm}$. Phase composition was studied locally by SAED (selected area electron diffraction) and globally by X-ray diffraction using PANalytical X'Pert PRO diffractometer equipped with $\mathrm{Cu}$ anode.

For a comparison between the SLM and the cast alloy, mechanical properties were tested. Uniaxial tensile tests were done with 3 samples using a universal testing machine LabTest 5.250SP1-VM. For compressive tests, cylinders of $8 \mathrm{~mm}$ in diameter and $12 \mathrm{~mm}$ in height (2:3 ratio) were used. Both tensile and compressive tests were accomplished at room temperature with a strain rate of $0.001 \mathrm{~s}^{-1}$. Hardness measurement was carried out on a Future-Tech FM-700 hardness tester and the Vickers hardness HV1 was determined. Fracture surfaces were studied by scanning electron microscopy.

\section{Results and Discussion}

\subsection{Microstructure}

\subsubsection{Hierarchical Microstructure of the Additively Manufactured $\mathrm{AlSi}_{9} \mathrm{Cu}_{3} \mathrm{Fe}$ Alloy}

As with other metallic materials prepared by SLM, the microstructure of the $\mathrm{AlSi}_{9} \mathrm{Cu}_{3} \mathrm{Fe}$ alloy also shows hierarchical heterogeneity, with length scales spanning nearly six orders of magnitude [26]. In the first magnification range, the additively manufactured $\mathrm{AlSi}_{9} \mathrm{Cu}_{3} \mathrm{Fe}$ alloy displays very characteristic macrostructure, which is related to the principle of its manufacture-the successive melting of the powder material by the laser beam. The laser beam was scanned across each powder layer according to the selected scanning strategy. By selective irradiation of the powder, melt pools were formed transiently [27]. After solidification, these melt pools are visible in the macrostructure of the processed alloy. The characteristic macrostructure of the studied $\mathrm{AlSi}_{9} \mathrm{Cu}_{3} \mathrm{Fe}$ alloy is shown in Figure 2. In the transversal section (Figure 2a), a top view of a layer is displayed. Here, several oval zones elongated in the same direction can be seen. The direction of laser scanning and the thickness of a laser track can be estimated. However, we can distinguish two types of elongated zones that overlap perpendicularly as the scanning direction changed with each layer by $90^{\circ}$. In our work, a 'chessboard' strategy was applied, meaning that every layer was divided into square boxes representing a chess board. The area of every box was scanned in one direction, with a firmly set hatching distance in between adjacent laser tracks. The scanning direction changed alternately for neighbor boxes. In the next layer, the directions were switched. In Figure $2 \mathrm{~b}$ representing the longitudinal section, consistent with the building direction, solidified melt pools can be observed directly. Their depth overpasses the layer thickness by a factor of about 1.5-4, which ensures a proper interconnection between layers.

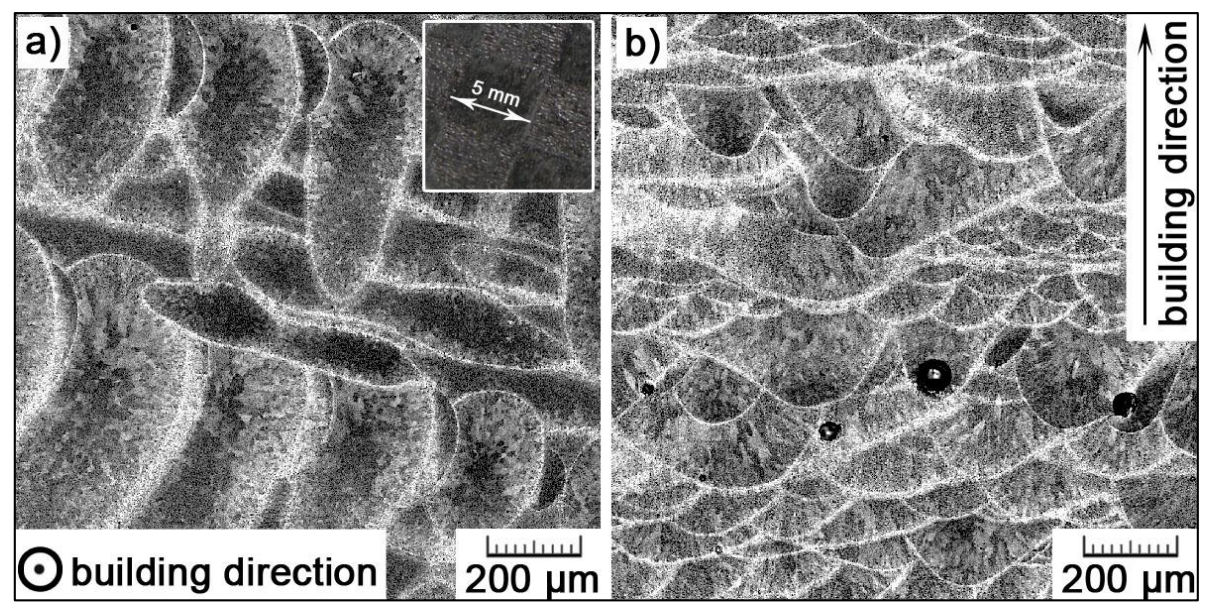

Figure 2. Macrostructure of the $\mathrm{SLM} \mathrm{AlSi}_{9} \mathrm{Cu}_{3} \mathrm{Fe}$ alloy in (a) transversal and (b) longitudinal section (image inserted in (a) represents a macroscopic view of the chessboard scanning strategy). 
Thanks to a slight contrast provided by the bright-field light microscopy, in Figure 2, individual grains can be estimated within the melt pools. However, much better information is provided by EBSD maps shown in Figure 3. Individual grains within a melt pool, as well as on its boundaries, can be clearly distinguished. The grain growth is directly influenced by temperature distribution within melt pools. At melt pools boundaries, where the heat is quickly conducted away by the already solidified and chilled material, fine equiaxed grains are formed by the heterogeneous nucleation occurring in front of the liquid-solid interface. The slowest heat dissipation occurs in the center of a melt pool where the highest temperature is kept for the longest period of time. Therefore, larger grains can be observed in melt pool interiors. As a melt pool is surrounded by already solidified material, the heat flows away radially. Therefore, within a melt pool, grains elongate in the direction of the thermal gradient, converging from boundaries of the melt pool to its center [28,29]. At the top surface, fine equiaxed grains are also formed as the cooling rate was reported (e.g., in References $[28,29])$ to reach $\sim 10^{6} \mathrm{~K} / \mathrm{s}$ here (compared to $\sim 10^{3} \mathrm{~K} / \mathrm{s}$ deeper in the melt pool).

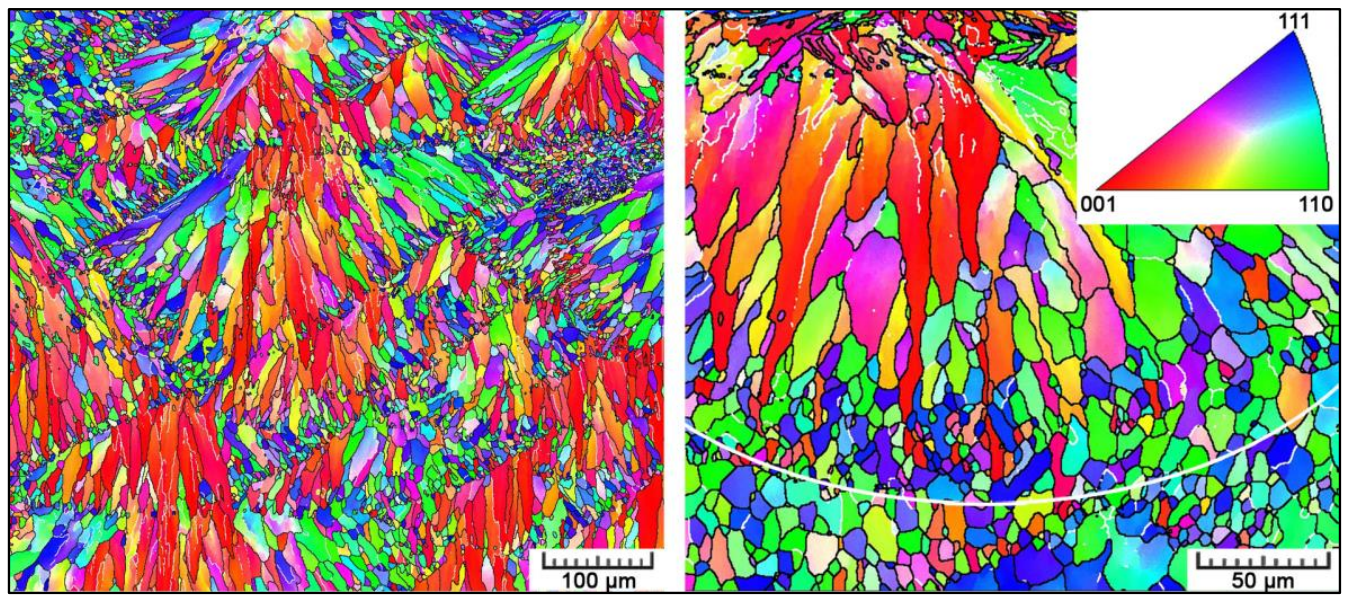

Figure 3. IPF maps constructed for fcc $\alpha-\mathrm{Al}$ phase with the orientation triangle corresponding to the building direction (high-angle boundaries in black, low-angle boundaries in white). White line indicates the melt pool boundary.

Due to a direct heat flow in the steep temperature gradient between the liquid melt pool and the previously consolidated layer, in alloys, the liquid may become undercooled due to the solute redistribution. That destabilizes the solidification front and generates a transition from a planar solidification mode to a cellular or dendritic mode. This transition occurs when the thermal gradient in the liquid phase at the solidification front becomes lower than the critical gradient, which is a function of the overall solute concentration, the solute diffusion coefficient in the liquid phase, the solute partition coefficient $k$, the solidification growth rate $R$, and the gradient of the equilibrium melting point. In multi-element alloys, the critical gradient derived for binary systems can be influenced by other alloying elements by changing the partitioning coefficients. The addition of an extra alloying element with a large partition coefficient increases the critical gradient, destabilizes the solidification front and promotes cellular solidification. The kinetic conditions favor the solidification of a low melting phase in the first step by ejecting high melting solute(s) at the solid-liquid interface. The low-melting phase thus occupies the core of the cells and the high-melting phase forms cell boundaries [30]. However, Prasanth and Eckert [31] suggested that apart from thermodynamic and kinetic considerations, also the surface tension aspect should be considered in rapidly solidified SLM specimens due to the SLM process specific characteristics. A melt pool is quite narrow, with at least one side surrounded by solid material, one or two sides surrounded with powder particles, and the top of the pool in contact with a protective gas. Such melting environments lead to a non-uniform heating and generation of thermo-capillary convection caused by strong surface tension effects. The cellular microstructure is thus a result of a surface tension driven instability termed the Benard Marangoni surface instability. 
When the cellular solidification mode is active, cubic materials are known to preferentially grow the cells along the $\left\langle\begin{array}{lll}1 & 0 & 0\end{array}\right\rangle$ crystal direction. Therefore, not only a morphological texture is created, but also a crystallographic texture. Small equiaxed grains at melt pool boundaries are newly nucleated grains among which a competitive growth occurred. However, at places where the $\langle 100\rangle$ direction of the substrate (previously solidified material) is along the heat flow direction, grains grow epitaxially. As only a few orientations can grow further towards the melt pool center, we can observe large elongated grains in melt pool interiors [29]. Based on the orientation triangle in Figure 3, one can see that elongated grains have their $\left\langle\begin{array}{lll}1 & 0 & 0\end{array}\right\rangle$ orientation parallel to the building direction, and in small equiaxed or slightly prolonged grains $\left\langle\begin{array}{llll}1 & 1 & 0\rangle\end{array}\right.$ and $\left\langle\begin{array}{llll}1 & 1 & 1\end{array}\right\rangle$ orientations prevail. Pole figures in Figure 4 testify to the $\langle 100\rangle$ cube texture along the building direction.
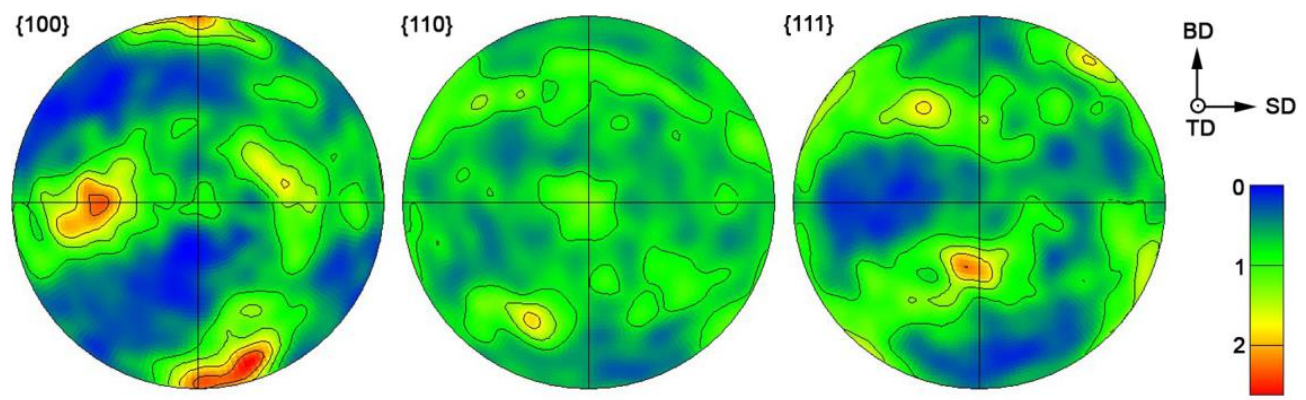

Figure 4. Pole figures constructed for fcc $\alpha-\mathrm{Al}$ phase. The orientation of the specimen coordinate system and the relative intensity of the diffraction peaks are shown.

When lowering the length scale further, very fine cellular-dendritic substructure can be observed within the grains (Figure 5). The solidification mode is mainly cellular, but occasionally, some side branches can be seen. It is a result of rapid cooling. Due to a very short persistence of a laser beam focused on a specific spot of a powder layer, the powder material is melted instantaneously, with high temperatures reached, and solidified the very next moment. Temperature gradients between the melt, and its surrounding (up to $10^{5} \mathrm{~K} / \mathrm{m}$ ) and the cooling rates $\left(10^{6}-10^{8} \mathrm{~K} / \mathrm{s}\right.$ ) are very high [32]. The formation of dendrites with multiple arms is impossible at such rates. Therefore, very fine cells are formed. They elongate in the direction of the highest temperature gradient (the elongation in one direction is clear from the longitudinal section in Figure $5 \mathrm{~b}$ ). Their size reaches $1.0 \pm 0.1 \mu \mathrm{m}$ in diameter and $3.7 \pm 0.8 \mu \mathrm{m}$ in length. In Figure $6 \mathrm{~b}$, it is visible that the cells orientate towards the center of the melt pools. The cells are formed by $\alpha$-Al solid solution and are surrounded by the network of eutectic Si. The eutectics fraction was assessed by image analysis and represents $29 \pm 5 \mathrm{vol} . \%$. As long as the cells have the same crystallographic orientation, they form one grain.

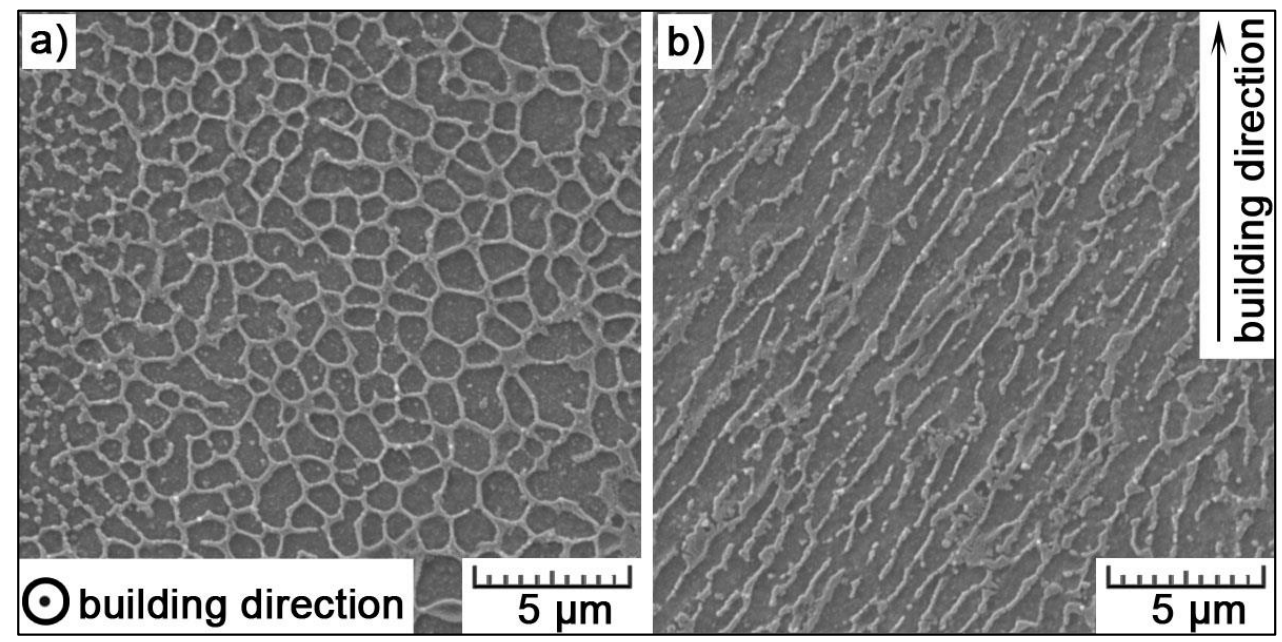

Figure 5. Fine cellular substructure in (a) transversal and (b) longitudinal section. 


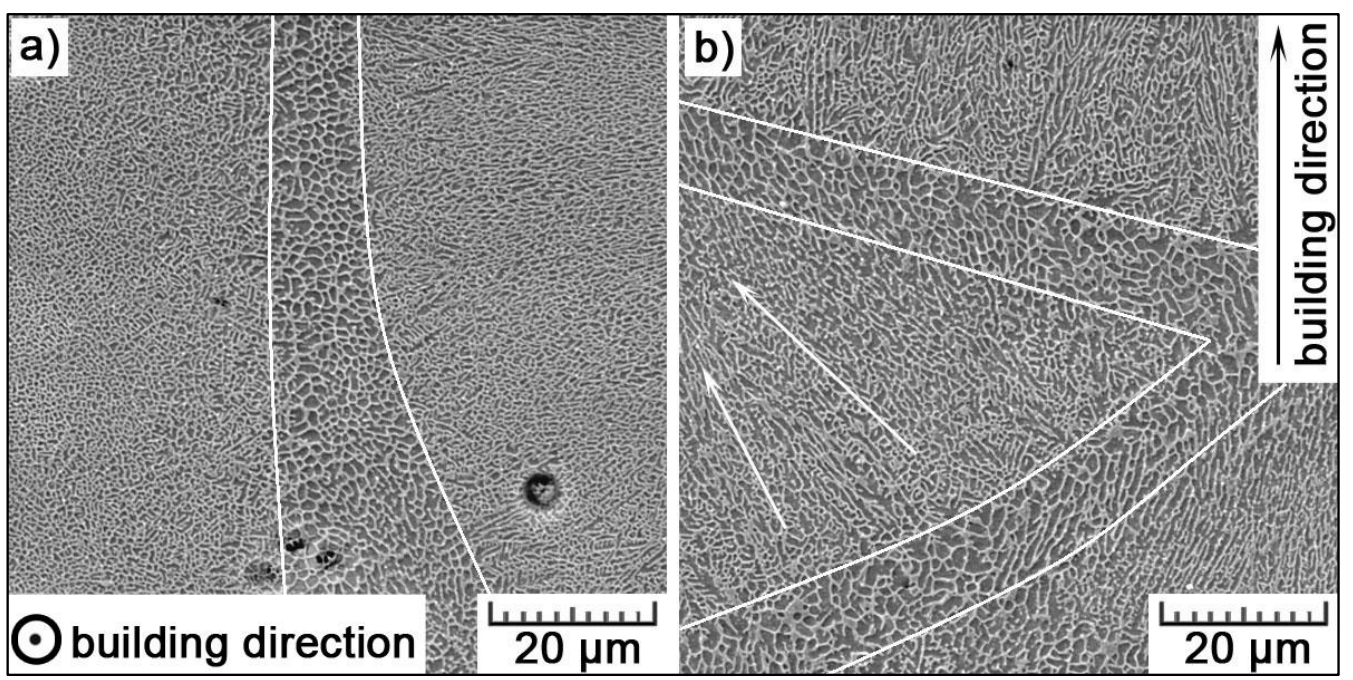

Figure 6. Melt pool boundaries in (a) transversal and (b) longitudinal section (arrows show the directionality of cells towards the melt pool center).

SEM images in Figure 6 show the boundaries of 'melt pools', about 10-15 $\mu \mathrm{m}$ thick. Here, the cellular substructure is coarser, what can be explained by the Gauss distribution of laser energy. The undercooling changes over the melt track; it reaches the maximum at the centerline, then gradually decreases and goes to the minimum at the boundary of the melt track [33]. From this point of view, the cellular size attains the minimum at the center of the melt track, while it reaches the maximum value on its boundary.

The greatest details are provided by TEM images in Figure 7. It can already be distinguished that the cell boundaries are formed by a network of silicon particles. These particles are cubic with an edge length of 30-70 nm. A significantly higher density of Si particles can be observed within the interior of melt pools (Figure $7 b$ ). Such a difference can be explained by a different thermal history. With higher undercooling inside melt pools, more numerous, and finer particles are formed [34].
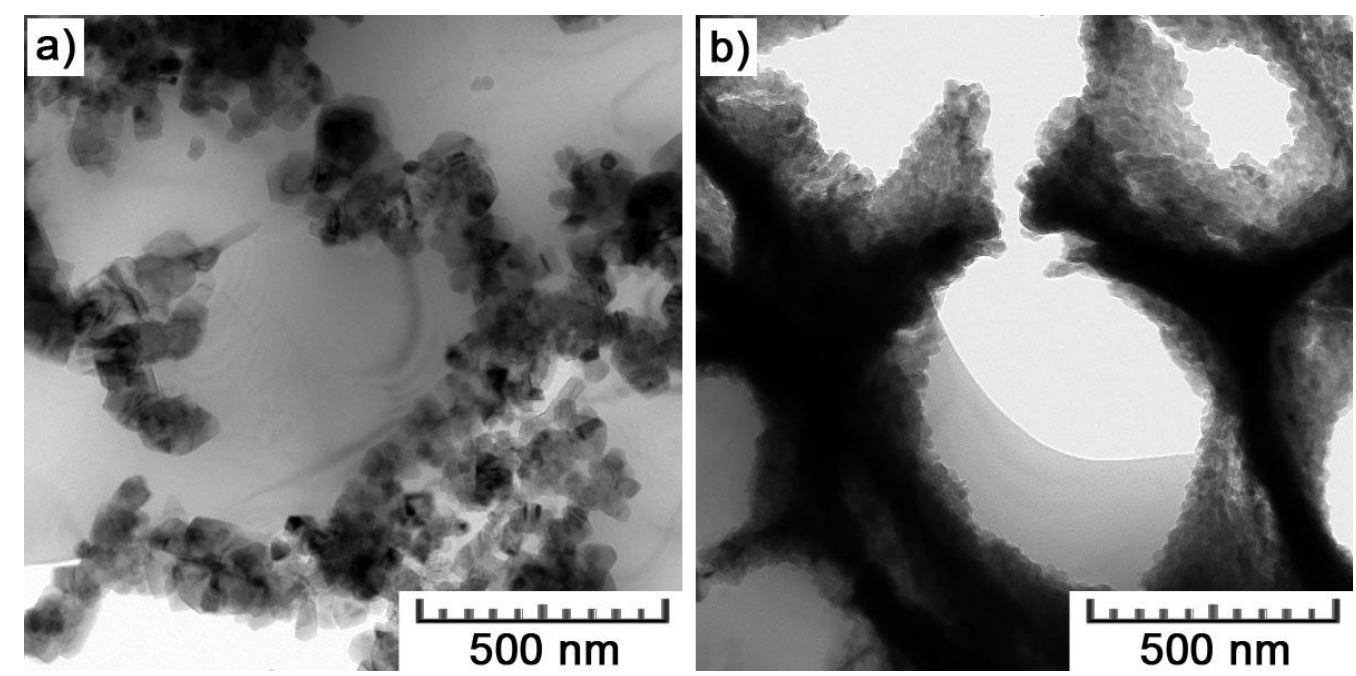

Figure 7. TEM bright field images obtained in the area of (a) a melt pool boundary and (b) a melt pool interior.

\subsubsection{Microstructure of the Conventionally Prepared HPDC $\mathrm{AlSi}_{9} \mathrm{Cu}_{3} \mathrm{Fe}$ Alloy}

The comparison of optical micrographs in Figure 8 clearly displays the difference between the additively manufactured and conventionally cast alloy. The as-cast microstructure consists of $\alpha-\mathrm{Al}$ dendrites, $\alpha-\mathrm{Al}+\mathrm{Si}$ eutectics and intermetallic phases (many phases can be possibly formed; 
binary (e.g., $\theta-\mathrm{Al}_{2} \mathrm{Cu}, \mathrm{Mg}_{2} \mathrm{Si}$ ), ternary (e.g., $\beta-\mathrm{Al}_{5} \mathrm{FeSi}, \mathrm{Al}_{9} \mathrm{Fe}_{2} \mathrm{Si}, \mathrm{Al}_{2} \mathrm{CuMg}, \mathrm{Al}_{15} \mathrm{Mn}_{3} \mathrm{Si}_{2}$ ), or quaternary (e.g., $\alpha-\mathrm{Al}_{15}(\mathrm{MnFe})_{3} \mathrm{Si}_{2}, \mathrm{~A}_{15} \mathrm{Mg}_{8} \mathrm{Si}_{6} \mathrm{Cu}_{2}$ ) [35-37]). The eutectics is of a lamellar type with platelets of $\mathrm{Si}$. The volume fraction of the eutectics was determined to be $51 \pm 5 \%$.

At first sight, the as-cast microstructure is much coarser than that in the AM material. The equivalent diameter of $18.4 \pm 4.5 \mu \mathrm{m}$ for dendritic branches overpasses the size of cells $(1.0 \pm 0.1 \mu \mathrm{m}$ in the cross-section) by a factor of 18 . That can be explained by the difference in cooling rate during both manufacturing processes. While cooling rates of HPDC ranges $10^{1}-10^{2} \mathrm{~K} / \mathrm{s}$ [38], they can reach up to $10^{8} \mathrm{~K} / \mathrm{s}$ during SLM [32]. Additionally, the size of Si plates is significantly larger (average length of $22 \pm 6 \mu \mathrm{m}$ and thickness of 0.1-2.0 $\mu \mathrm{m}$ ) than nano-sized cubes of $\mathrm{Si}$ forming the cellular network (Figure 7). Generally, such plate-like morphology of Si is not good for mechanical properties, because Si platelets are hard and brittle, and so reduce ductility and tensile strength. Therefore, there are various approaches used to affect the morphology of $\mathrm{Si}$ in an appropriate manner [39].
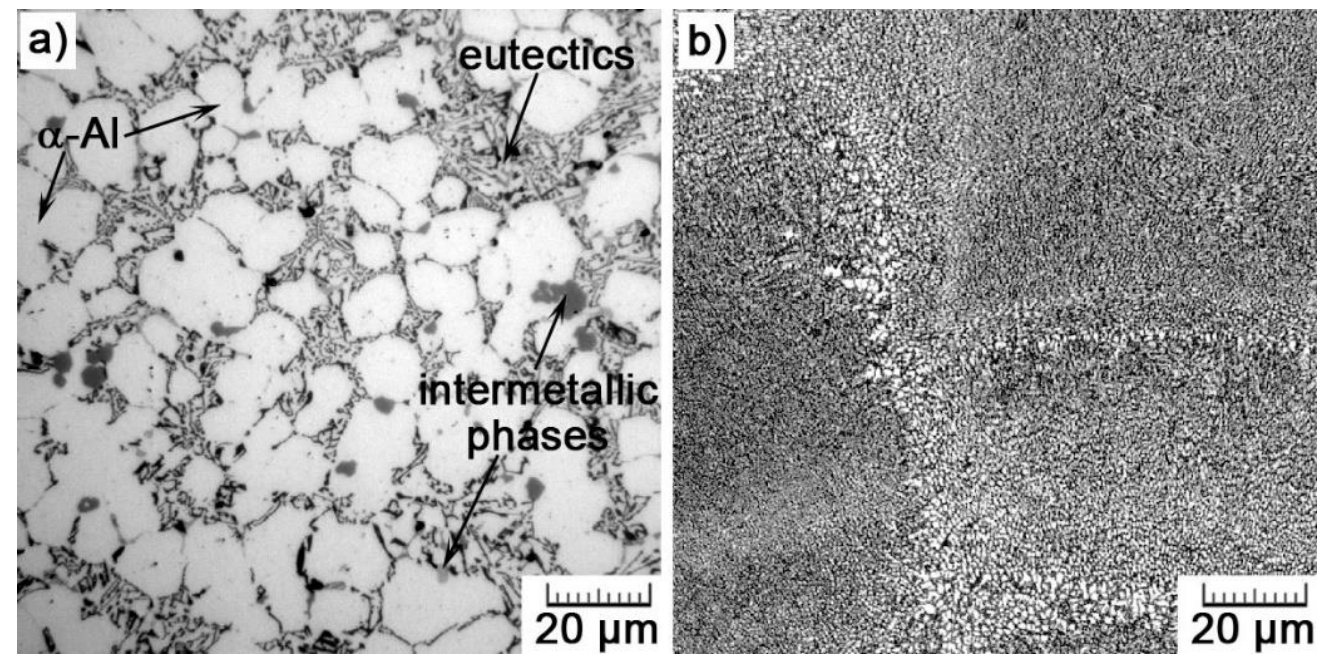

Figure 8. Comparison between (a) as-cast (HPDC) and (b) SLM microstructures.

\subsection{Chemical and Phase Composition}

\subsubsection{The Additively Manufactured $\mathrm{AlSi}_{9} \mathrm{Cu}_{3} \mathrm{Fe}$ Alloy}

Due to the very fine microstructure of the AM alloy, the EDS analysis was carried out in the STEM regime. It revealed that the oversaturated solid solution of $\alpha$-Al contains $2.2 \pm 0.3 \mathrm{wt} . \%$ of $\mathrm{Si}$ and $4.6 \pm 2.7 \mathrm{wt}$. $\%$ of $\mathrm{Cu}$. At high solidification velocities (here up to $10^{8} \mathrm{~K} / \mathrm{s}$ ), the deviation of liquidus and solidus lines from equilibrium values occurs, leading to a solute trapping effect. A transition from diffusion-controlled to diffusion-less solidification is predicted as the interface speed exceeds the maximum speed with which solute atoms can diffuse across the interface and are thus pinned down in the product phase [40].

In the area of the Si network, the EDS analysis was already distorted by the surroundings. Nevertheless, it showed almost pure $\mathrm{Si}$, which was confirmed by diffraction (Figure 9). Diffraction rings perfectly matched crystalline planes of $\mathrm{Si}$ with the diamond crystalline structure. Another type of particle (Figure 10a) was detected in the area of the intercellular network as well. It was shown to be composed only of $\mathrm{Al}$ and $\sim 30$ at. $\%$ of $\mathrm{Cu}$ (Table 3, 53.7 weight $\%$ corresponds to $\sim 30$ atomic $\%$ ). It thus corresponds to the $\mathrm{CuAl}_{2}$ phase. X-ray diffraction determined 2 vol. $\%$ of this phase in the bulk material.

Iron was detected in the areas of fine Si particles in the interior of melt pools (Figure 10b). As no specific particles were distinguished in the cloud of Si particles, it is not clear what type of phase Fe forms. Along with $4.8 \pm 0.8 \mathrm{wt} . \%$ of Fe, a small amount of oxygen was also detected (2.8 $\pm 0.2 \mathrm{wt} . \%)$. Data from point EDS analyses, complementing Figure 10, are given in Table 3. 

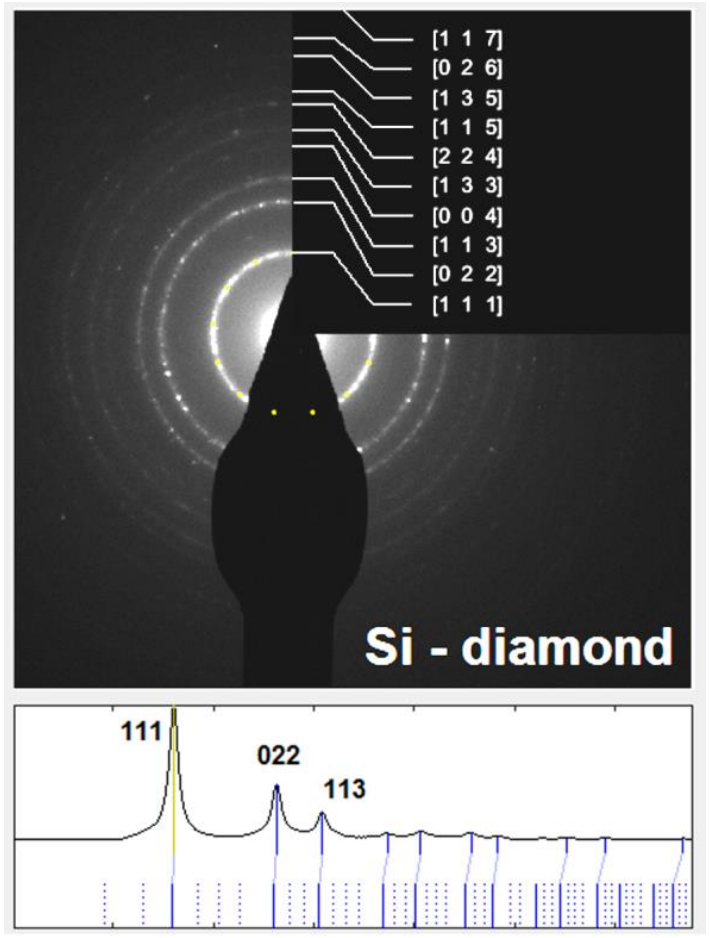

Figure 9. Diffraction pattern and its evaluation.
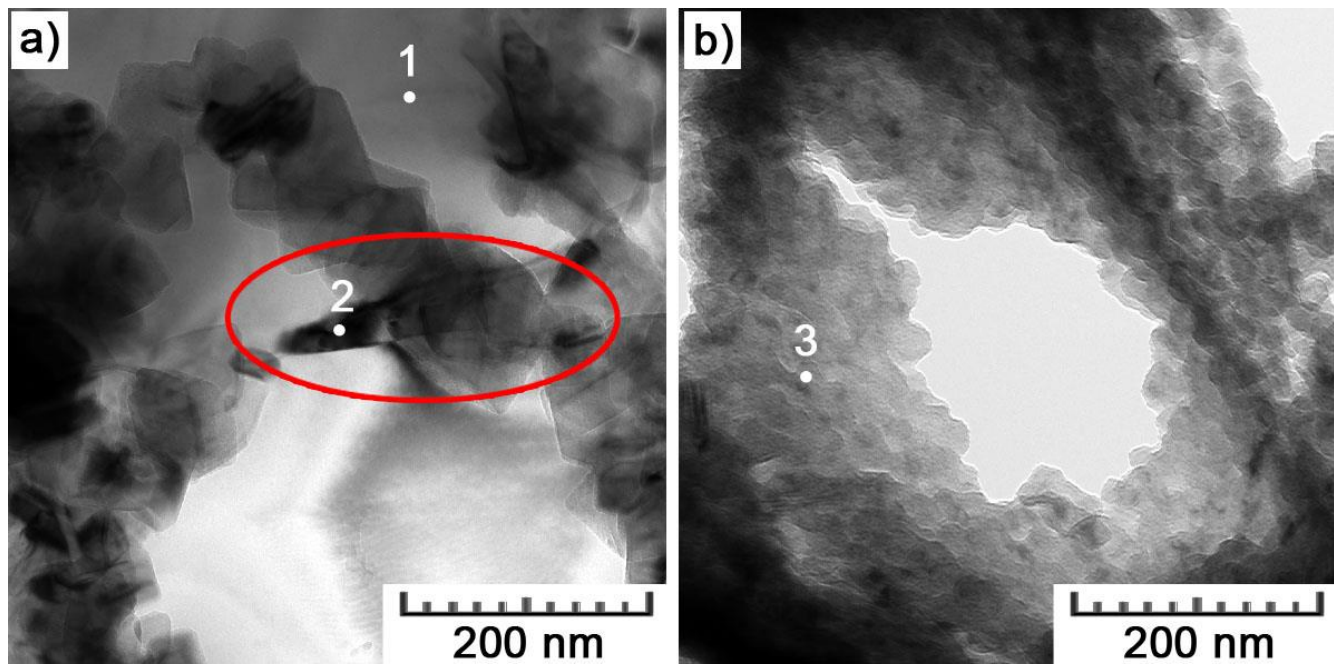

Figure 10. TEM bright field images showing (a) a $\mathrm{CuAl}_{2}$ particle and (b) area of Fe detection in the intercellular network (numbered points represent locations of point EDS analyses).

Table 3. Point EDS analyses (wt.\%) (location of points in Figure 9).

\begin{tabular}{ccccccc}
\hline Spectrum & & $\mathbf{A l}$ & $\mathbf{S i}$ & $\mathbf{C u}$ & $\mathbf{F e}$ & $\mathbf{O}$ \\
\hline 1 & solid solution & 92.5 & 2.2 & 5.3 & & \\
2 & $\mathrm{CuAl}_{2}$ phase & 46.3 & & 53.7 & & \\
3 & area of $\mathrm{Fe}$ detection & 18.6 & 71.1 & 3.1 & 4.3 & 2.8 \\
\hline
\end{tabular}

\subsubsection{The Conventionally Manufactured $\mathrm{AlSi}_{9} \mathrm{Cu}_{3} \mathrm{Fe}$ Alloy}

The distribution of constituting elements within the $\mathrm{AlSi}_{9} \mathrm{Cu}_{3} \mathrm{Fe}$ alloy prepared by HPDC is illustrated by EDS map in Figure 11. There are two main structural constituents-primary solid solution, and eutectics. The solid solution contains $1.9 \pm 0.2 \mathrm{wt} . \%$ of $\mathrm{Si}$ and $0.9 \pm 0.2 \mathrm{wt} . \%$ of $\mathrm{Cu}$. Such super-saturation can be referred to the elevated cooling rate and pressure during the HPDC process. 
In eutectics, Si lamellae can be observed. Except these two main structural constituents, there are also two types of intermetallic phases. We were not able to determine their accurate composition due to the resolution limits of the EDS analysis. However, as EDS maps suggest, small pentagonal phases are formed mainly by $\mathrm{Fe}, \mathrm{Mn}$, and $\mathrm{Cr}$, while larger irregular phases are predominantly formed by $\mathrm{Al}$ and $\mathrm{Cu}$, but contain also small amounts of $\mathrm{Mg}, \mathrm{Ni}, \mathrm{Sn}$, and Fe. Therefore, we can suggest that it concerns $\mathrm{Al}_{15}(\mathrm{MnFe})_{3} \mathrm{Si}_{2}$ and $\mathrm{Al}_{2} \mathrm{Cu}$ phases, respectively. Their morphology and chemical compositions are shown in detail in Figure 12 and Table 4. In case of the $\mathrm{Al}_{2} \mathrm{Cu}$ phase, it is probably a ternary eutectic form $\left(\mathrm{Al}-\mathrm{Al}_{2} \mathrm{Cu}-\mathrm{Si}\right)$ that often precipitates on pre-existing Si-particles or Fe-phases, what explains the detection of other elements [36].
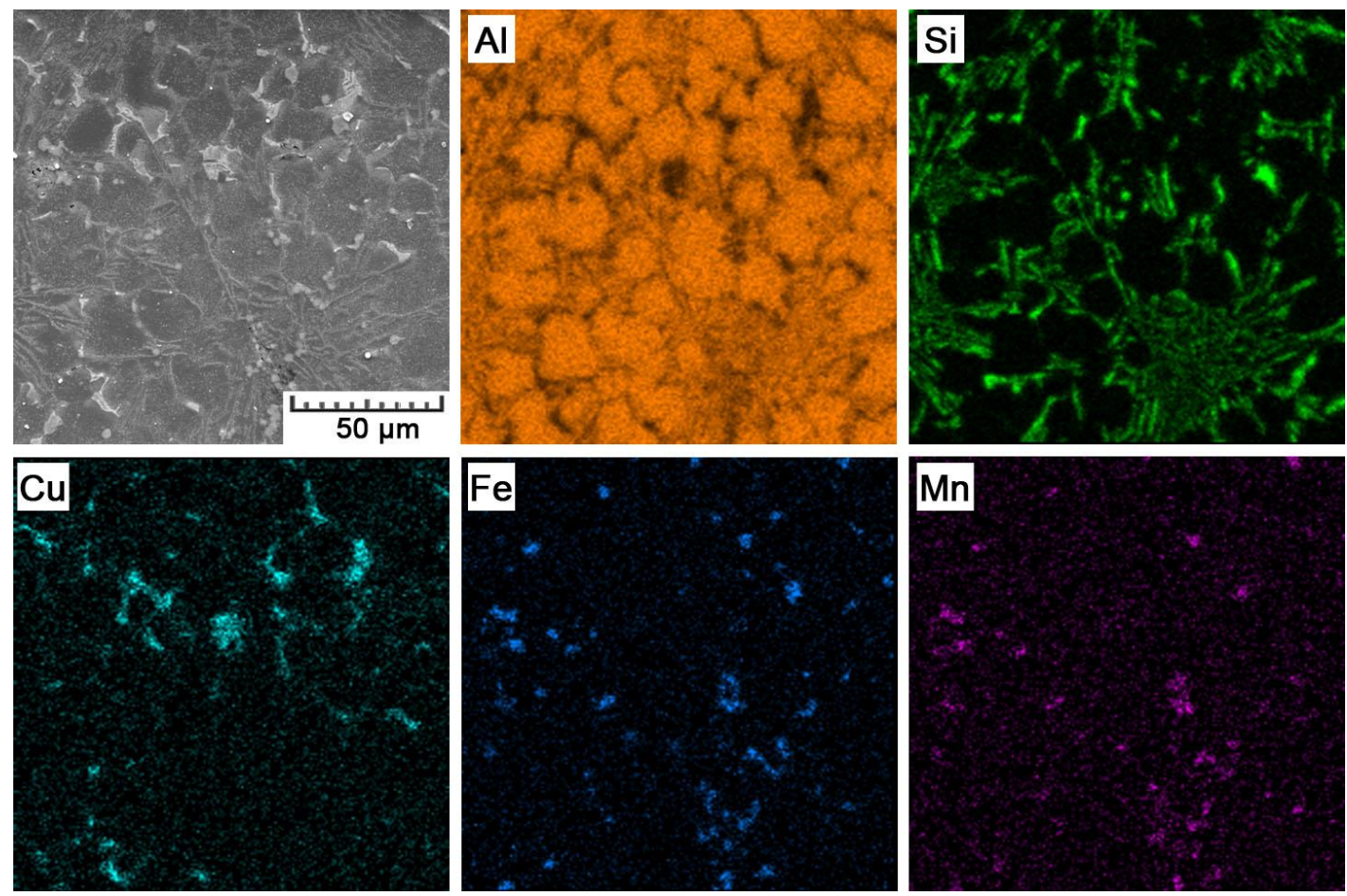

Figure 11. EDS maps showing the distribution of alloying elements in the HPDC $\mathrm{AlSi}_{9} \mathrm{Cu}_{3} \mathrm{Fe}$ alloy.

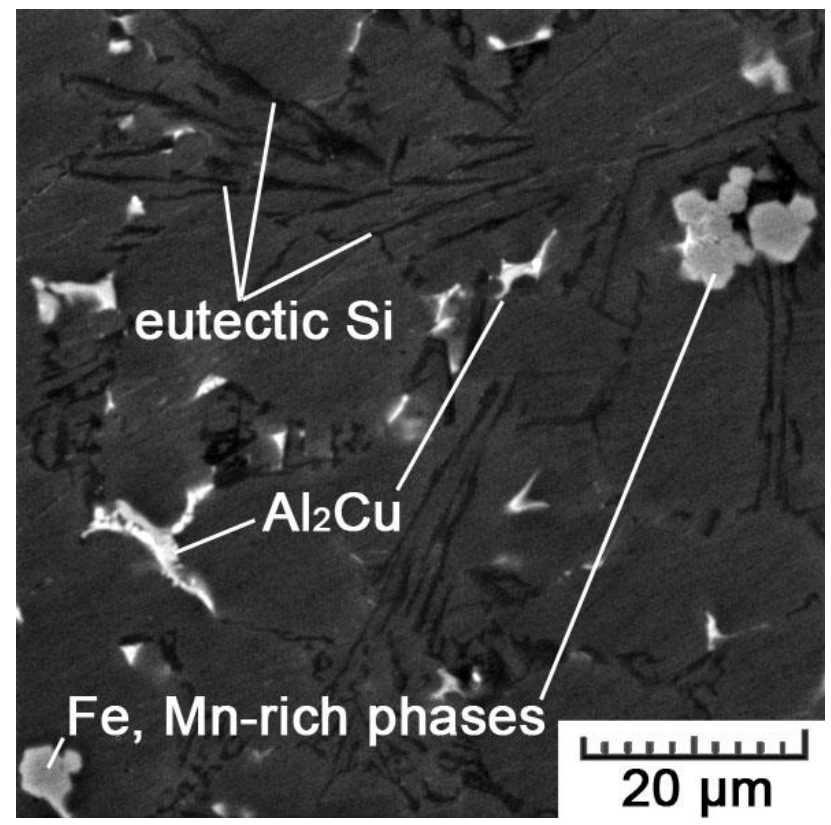

Figure 12. SEM image showing different types of phases in the HPDC $\mathrm{AlSi}_{9} \mathrm{Cu}_{3} \mathrm{Fe}$ alloy. 
Table 4. Chemical composition (at.\%) of different types of phases in the HPDC $\mathrm{AlSi}_{9} \mathrm{Cu}_{3} \mathrm{Fe}$ alloy (Figure 12).

\begin{tabular}{|c|c|c|}
\hline & $\mathrm{Al}_{2} \mathrm{Cu}$ & $\mathrm{Al}_{15}(\mathrm{MnFe})_{3} \mathrm{Si}_{2}$ \\
\hline $\mathrm{Al}$ & $69.5 \pm 3.5$ & $71.5 \pm 2.7$ \\
\hline $\mathrm{Si}$ & $7.4 \pm 3.0$ & $12.2 \pm 0.7$ \\
\hline $\mathrm{Cu}$ & $17.6 \pm 2.8$ & $1.1 \pm 2.3$ \\
\hline $\mathrm{Fe}$ & $0.3 \pm 0.1$ & $9.2 \pm 1.0$ \\
\hline Mn & & $5.3 \pm 0.7$ \\
\hline $\mathrm{Ni}$ & $0.6 \pm 0.0$ & \\
\hline $\mathrm{Zn}$ & $0.7 \pm 0.1$ & \\
\hline Sn & $0.1 \pm 0.0$ & \\
\hline
\end{tabular}

\subsection{Mechanical Properties}

Figure 13 brings a comparison of stress-strain curves obtained for the SLM and HPDC $\mathrm{AlSi}_{9} \mathrm{Cu}_{3} \mathrm{Fe}$ alloy under tensile and compressive loading. Values of selected mechanical properties are then summarized in Table 5. The curves show significantly higher strength, but also plasticity of the SLM alloy, which is a unique asset. While it has been a longstanding challenge to overcome the strength-ductility trade-off that exists ubiquitously in pure metals and alloys, SLM has turned out to be capable of that [26]. Several papers has reported that the contradictory strength-plasticity relationship was overcome in some materials (e.g., stainless steel [26], AlSi10Mg alloy [41] or Ti6Al4V [42]).

Very fine cellular substructure (Figure 5) and the existence of the strongly oversaturated solid solution, both resulting from high cooling rates during the SLM process, yielded in stronger strengthening effect. As there was not such a significant difference in the content of solute atoms in the $\alpha$-Al solid solution, it can be expected that the Hall-Petch strengthening is dominant compared to the contribution of solid solution strengthening. The Hall-Petch contribution can be determined according to the following equation:

$$
\Delta \sigma_{H P}=k d^{-1 / 2},
$$

where $k$ is the Hall-Petch coefficient and $d$ is the grain size. The $k$ value is not known for the investigated material, but for a simplified estimation, values reported in other research works can be used. In [43], coefficients for rapidly solidified aluminium alloys strengthened with particles were reported to range between 150 and $170 \mathrm{MPa} \mu \mathrm{m}^{1 / 2}$. When the average grain sizes determined for the additively manufactured and conventionally $\mathrm{HPDC}$ cast $\mathrm{AlSi}_{9} \mathrm{Cu}_{3} \mathrm{Fe}$ alloy $(3.7 \mu \mathrm{m}$ and $18.4 \mu \mathrm{m}$, respectively) are used in the Equation (1), the difference between the Hall-Petch contribution of both compared materials ranges $43-48 \mathrm{MPa}$. The real difference between TYS values reported in Table 5 is $46 \mathrm{MPa}$, which perfectly falls into this range. Therefore, we can deduce that the refinement brought by SLM plays the dominant role in increasing the strength of the $\mathrm{AlSi}_{9} \mathrm{Cu}_{3} \mathrm{Fe}$ alloy.

Moreover, the morphology and size of eutectic silicon are known to play a very important role, especially on material plasticity [33]. Therefore, small cubic particles of Si (Figure 7) are much more favorable than lamellar eutectic Si in the HPDC alloy (Figure 12). In conventionally cast material, acicular silicon acts as crack initiation sites and consequently results in low ductility. For that reason, different ways of the refinement of the eutectic microstructure of Al-Si alloys have been extensively investigated [44-47]. The refinement of the Si phase can be achieved by controlling the nucleation and growth of the eutectic grains. Usually, two different approaches are applied: elemental additions and rapid solidification. However, both have their drawbacks. Refining elements often evaporate, oxidize, and the modification can be thus hard to control. On the other hand, for most castings, rapid solidification is impossible to occur uniformly in the entire volume, and thus, such an approach is limited to very small and thin parts only [2]. Nevertheless, SLM circumvents these drawbacks. Due to the gradual melting and solidification, laser heats only a very small volume of a material during a short interaction time, so that high cooling rates $\left(10^{6}-10^{8} \mathrm{~K} / \mathrm{s}\right.$ [32] $)$ are maintained throughout the entire volume of a fabricated part. 

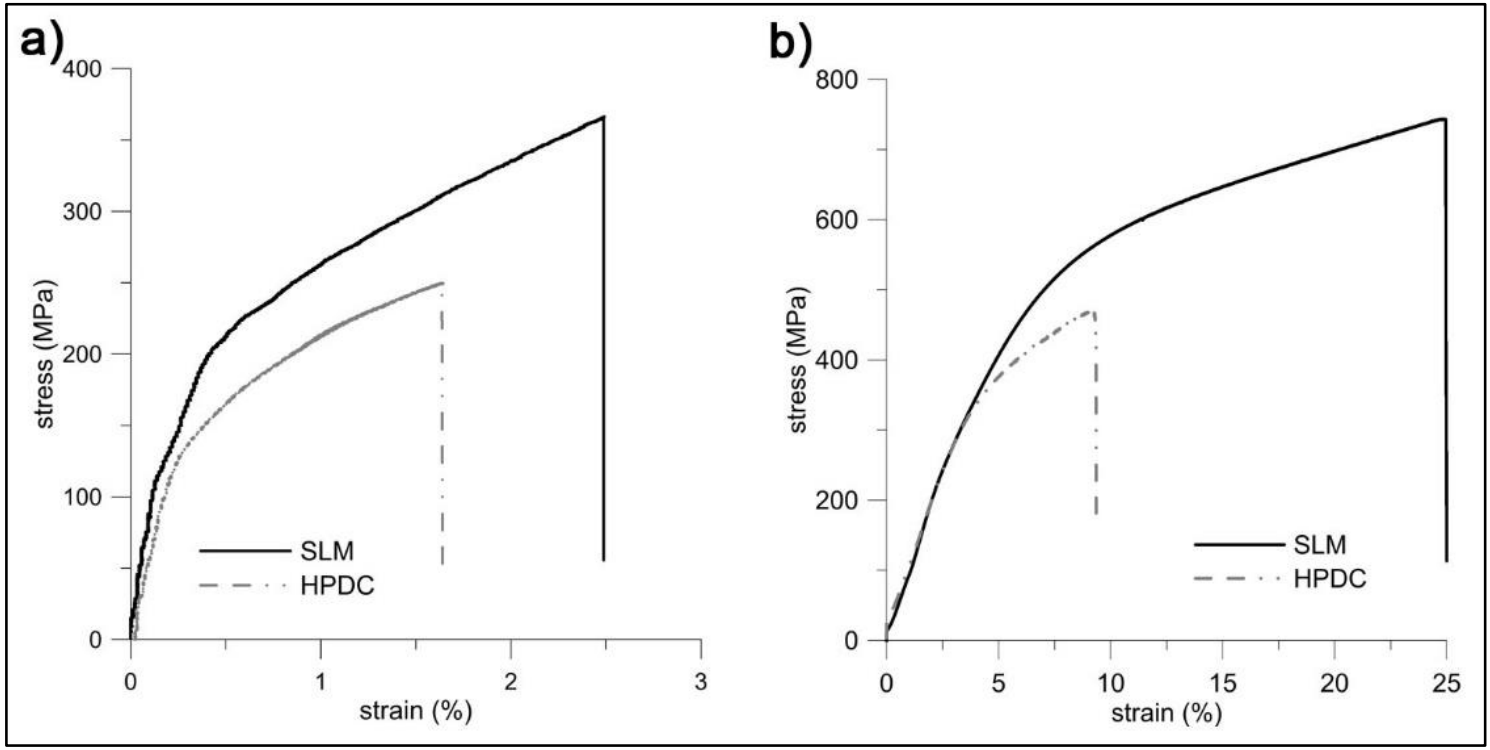

Figure 13. Representative stress-strain curves showing the comparison between the $\mathrm{AlSi}_{9} \mathrm{Cu}_{3} \mathrm{Fe}$ alloy prepared by SLM and conventional HPDC in mechanical properties: (a) Tension and (b) compression.

Table 5. Measured mechanical properties of the SLM and HPDC $\mathrm{AlSi}_{9} \mathrm{Cu}_{3} \mathrm{Fe}$ alloy (TYS, tensile yield strength, UTS, ultimate tensile strength, A, elongation, CYS, compressive yield strength, UCS, ultimate compressive strength, and HV1, Vicker's hardness with $1 \mathrm{~kg}$ load).

\begin{tabular}{ccccccc}
\hline \multirow{2}{*}{$\begin{array}{c}\text { Production } \\
\text { Technology }\end{array}$} & \multicolumn{3}{c}{ Tension } & \multicolumn{2}{c}{ Compression } & Hardness \\
\cline { 2 - 6 } & TYS (MPa) & UTS (MPa) & A (\%) & CYS (MPa) & UCS (MPa) & HV1 \\
\hline SLM & $219 \pm 20$ & $374 \pm 11$ & $1.9 \pm 0.2$ & $375 \pm 30$ & $752 \pm 41$ & $135.2 \pm 4.8$ \\
HPDC & $173 \pm 14$ & $257 \pm 17$ & $1.2 \pm 0.5$ & $342 \pm 14$ & $482 \pm 58$ & $108.1 \pm 3.1$ \\
\hline
\end{tabular}

In $\mathrm{Al}-\mathrm{Si}$ alloys containing $\mathrm{Fe}$, the formation of $\beta-\mathrm{Al}_{5} \mathrm{FeSi}$ is also critical in terms of plasticity. This needle-like hard phase brings high stress concentrations and increases crack initiation. Its detrimental effect can be overcome by two approaches; rapid cooling or addition of a suitable neutralizing element [36]. In HPDC, manganese was added to convert the monoclinic $\beta$-phase to cubic $\alpha$-phase $\mathrm{Al}_{15}(\mathrm{MnFe})_{3} \mathrm{Si}_{2}$. In the case of SLM, there was no need of additional elements as high cooling rates prevented the formation of intermetallic phases by trapping them in the solid solution.

In tension, the increase in elongation is not so pronounced as the plasticity is limited due to the presence of defects. The total porosity of the samples was determined to represent $0.5 \mathrm{vol} . \%$. Typical defects can be seen in Figure 14a in the fracture surface of an SLM sample subjected to the tensile test. It concerns two types of defects, both showing spherical shape. First, larger voids are so-called key-hole defects which are formed at the bottom of deep melt pools (as it can be seen in Figure $2 b$ ) due to the melt instability and evaporation of the metal by high-power laser beam. As the vapor cavity collapses, a void is formed. Secondly, smaller voids result from gas entrapment (probably oxygen) and its inability to escape from the melt during rapid solidification [29]. The fracture topography shows a ductile mode of fracture with extremely fine morphology (Figure 14b), which is linked to the Si enriched dendrite cell network. It is assumed that the samples fail along the cell network, where the fracture initiates due to the higher hardness caused by Si enrichment and reduced ductility compared to the Al-enriched cells [48]. 


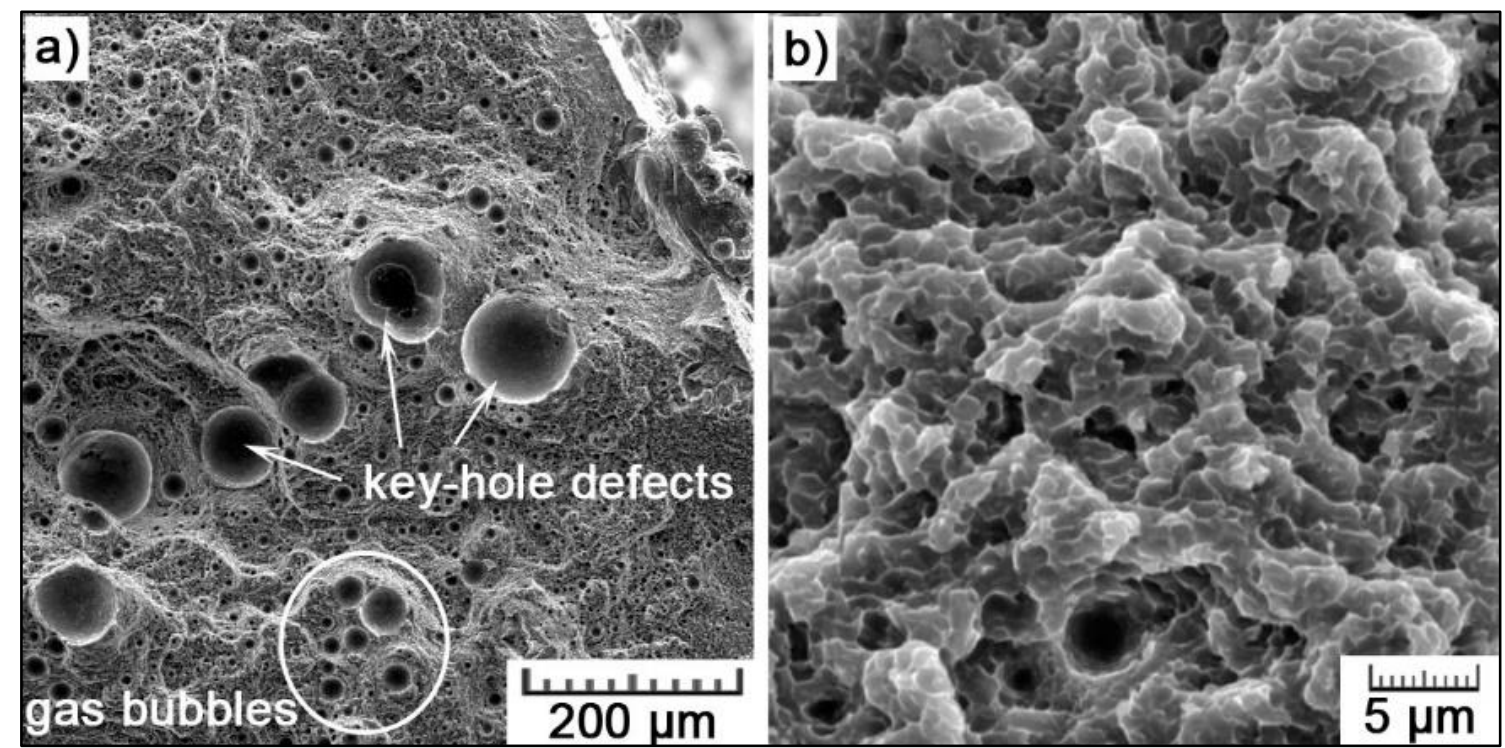

Figure 14. Fracture surface of the SLM AlSi ${ }_{9} \mathrm{Cu}_{3} \mathrm{Fe}$ alloy: (a) key-hole defects and gas bubbles; and (b) fracture morphology.

\section{Conclusions}

In this study, the $\mathrm{AlSi}_{9} \mathrm{Cu}_{3} \mathrm{Fe}$ alloy, additively manufactured by SLM, was comprehensively characterized and compared with the same alloy, but prepared conventionally by HPDC. Compared to as-cast microstructure consisting of $\alpha$-Al dendrites and lamellar Al-Si eutectics, SLM yields in hierarchically heterogeneous microstructure. Grains are arranged in melt pools representing material melted and solidified by single laser tracks in the direction of the highest temperature gradient. They exhibit very fine cellular substructure in which the cells of $\alpha-\mathrm{Al}$ solid solution oversaturated in $\mathrm{Si}$ and $\mathrm{Cu}$ are separated by eutectic network formed by cubic particles of pure $\mathrm{Si}$, here 30-70 $\mathrm{nm}$ in size. Altogether, the size of the cells lower than $1 \mu \mathrm{m}$, nanoscale cubic Si particles and oversaturation of the solid solution contribute to a significantly higher strength of the alloy. Microstructural features also favor the material plasticity. By elimination of internal defect, the plasticity could even be improved. Our study has thus shown that, compared to HPDC, SLM can desirably improve the performance of the $\mathrm{AlSi}_{9} \mathrm{Cu}_{3} \mathrm{Fe}$ alloy and extend its potential applications, which is also due to the possibility of SLM to produce complex lightweight structures.

Author Contributions: Conceptualization: D.V. and P.L.; Methodology: M.F. and M.V.; Investigation: M.F., D.D. and M.V.; Resources: D.V. and P.L.; Data Curation: M.F.; Writing-Original Draft Preparation: M.F.; Writing—Review \& Editing: P.L.; Visualization: M.F.; Supervision: D.V.; Project Administration: D.V. and P.L.; Funding Acquisition: D.V. and P.L.

Funding: This research was funded by the Czech Science Foundation [project no. P108/12/G043] and the Czech Ministry of Education, Youth and Sports [project no. LM2015087].

Acknowledgments: The authors also wish to thank the NETME Centre (namely D. Palousek) for the manufacture of the testing samples.

Conflicts of Interest: The authors declare no conflict of interest. The funders had no role in the design of the study; in the collection, analyses, or interpretation of data; in the writing of the manuscript, and in the decision to publish the results.

\section{References}

1. Panušková, M.; Tillová, E.; Chalupová, M. Relation between mechanical properties and microstructure of cast aluminum alloy $\mathrm{AlSi}_{9} \mathrm{Cu}_{3}$. Strength Mater. 2008, 40, 98-101. [CrossRef] 
2. Li, X.P.; Wang, X.J.; Saunders, M.; Suvorova, A.; Zhang, L.C.; Liu, Y.J.; Fang, M.H.; Huang, Z.H.; Sercombe, T.B. A selective laser melting and solution heat treatment refined Al-12Si alloy with a controllable ultrafine eutectic microstructure and 25\% tensile ductility. Acta Mater. 2015, 95, 74-82. [CrossRef]

3. International Organization for Standardization. Aluminium and Aluminium Alloys-Castings-Chemical Composition and Mechanical Properties; ISO 3522:2007; International Organization for Standardization: Geneva, Switzerland, 2007.

4. Vončina, M.; Močnik, N.; Nagode, A.; Stoić, A.; Bizjak, M. Dependence of mechanical properties on Cu content in $\mathrm{AlSi}_{9} \mathrm{Cu}_{3}(\mathrm{Fe})$ alloy. Tehnički Vjesnik 2017, 24, 229-231. [CrossRef]

5. Sanna, F.; Fabrizi, A.; Ferraro, S.; Timelli, G.; Ferro, P.; Bonollo, F. Multiscale characterisation of $\mathrm{AlSi}_{9} \mathrm{Cu}_{3}(\mathrm{Fe})$ die casting alloys after $\mathrm{Cu}, \mathrm{Mg}, \mathrm{Zn}$ and $\mathrm{Sr}$ addition. La Metall. Ital. 2013, 4, 13-24.

6. DebRoy, T.; Wei, H.L.; Zuback, J.S.; Mukherjee, T.; Elmer, J.W.; Milewski, J.O.; Beese, A.M.; Wilson-Heid, A.; De, A.; Zhang, W. Additive manufacturing of metallic components-Process, structure and properties. Prog. Mater. Sci. 2018, 92, 112-224. [CrossRef]

7. Fousova, M.; Kubasek, J.; Vojtech, D.; Fojt, J.; Capek, J. 3D printed porous stainless steel for potential use in medicine. IOP Conf. Ser. Mater. Sci. Eng. 2017, 179, 012025. [CrossRef]

8. Fousova, M.; Vojtech, D.; Kubasek, J.; Jablonska, E.; Fojt, J. Promising characteristics of gradient porosity Ti-6Al-4V alloy prepared by SLM process. J. Mech. Behav. Biomed. Mater. 2017, 69, 368-376. [CrossRef] [PubMed]

9. Zhao, X.; Li, S.; Zhang, M.; Liu, Y.; Sercombe, T.B.; Wang, S.; Hao, Y.; Yang, R.; Murr, L.E. Comparison of the microstructures and mechanical properties of Ti-6Al-4V fabricated by selective laser melting and electron beam melting. Mater. Des. 2016, 95, 21-31. [CrossRef]

10. Fousova, M.; Vojtech, D.; Doubrava, K.; Daniel, M.; Lin, C.F. Influence of inherent surface and internal defects on mechanical properties of additively manufactured Ti6Al4V alloy: Comparison between selective laser melting and electron beam melting. Materials 2018, 11, 537. [CrossRef] [PubMed]

11. Murr, L.E.; Gaytan, S.M.; Ramirez, D.A.; Martinez, E.; Hernandez, J.; Amato, K.N.; Shindo, P.W.; Medina, F.R.; Wicker, R.B. Metal Fabrication by Additive Manufacturing Using Laser and Electron Beam Melting Technologies. J. Mater. Sci. Technol. 2012, 28, 1-14. [CrossRef]

12. Brandl, E.; Heckenberger, U.; Holzinger, V.; Buchbinder, D. Additive manufactured AlSi10Mg samples using Selective Laser Melting (SLM): Microstructure, high cycle fatigue, and fracture behavior. Mater. Des. 2012, 34, 159-169. [CrossRef]

13. Kimura, T.; Nakamoto, T. Microstructures and mechanical properties of A356 (AlSi7Mg0.3) aluminum alloy fabricated by selective laser melting. Mater. Des. 2016, 89, 1294-1301. [CrossRef]

14. Rao, J.H.; Zhang, Y.; Fang, X.; Chen, Y.; Wu, X.; Davies, C.H.J. The origins for tensile properties of selective laser melted aluminium alloy A357. Addit. Manuf. 2017, 17, 113-122. [CrossRef]

15. Li, X.P.; O’Donnell, K.M.; Sercombe, T.B. Selective laser melting of Al-12Si alloy: Enhanced densification via powder drying. Addit. Manuf. 2016, 10, 10-14. [CrossRef]

16. Leary, M.; Mazur, M.; Elambasseril, J.; McMillan, M.; Chirent, T.; Sun, Y.; Qian, M.; Easton, M.; Brandt, M. Selective laser melting (SLM) of AlSi12Mg lattice structures. Mater. Des. 2016, 98, 344-357. [CrossRef]

17. Kimura, T.; Nakamoto, T.; Mizuno, M.; Araki, H. Effect of silicon content on densification, mechanical and thermal properties of Al-xSi binary alloys fabricated using selective laser melting. Mater. Sci. Eng. A 2017, 682, 593-602. [CrossRef]

18. Kang, N.; Coddet, P.; Chen, C.; Wang, Y.; Liao, H.; Coddet, C. Microstructure and wear behavior of in-situ hypereutectic Al-high Si alloys produced by selective laser melting. Mater. Des. 2016, 99, 120-126. [CrossRef]

19. Kaufmann, N.; Imran, M.; Wischeropp, T.M.; Emmelmann, C.; Siddique, S.; Walther, F. Influence of Process Parameters on the Quality of Aluminium Alloy EN AW 7075 Using Selective Laser Melting (SLM). Phys. Procedia 2016, 83, 918-926. [CrossRef]

20. Spierings, A.B.; Dawson, K.; Dumitraschkewitz, P.; Pogatscher, S.; Wegener, K. Microstructure characterization of SLM-processed Al-Mg-Sc-Zr alloy in the heat treated and HIPed condition. Addit. Manuf. 2018, 20, 173-181. [CrossRef]

21. Lopez-Botello, O.; Martinez-Hernandez, U.; Ramírez, J.; Pinna, C.; Mumtaz, K. Two-dimensional simulation of grain structure growth within selective laser melted AA-2024. Mater. Des. 2017, 113, 369-376. [CrossRef]

22. Zheng, L.; Liu, Y.; Sun, S.; Zhang, H. Selective laser melting of Al-8.5Fe-1.3V-1.7Si alloy: Investigation on the resultant microstructure and hardness. Chin. J. Aeronaut. 2015, 28, 564-569. [CrossRef] 
23. Prashanth, K.G.; Shakur Shahabi, H.; Attar, H.; Srivastava, V.C.; Ellendt, N.; Uhlenwinkel, V.; Eckert, J.; Scudino, S. Production of high strength Al85Nd8Ni5Co2 alloy by selective laser melting. Addit. Manuf. 2015, 6, 1-5. [CrossRef]

24. Kürnsteiner, P.; Wilms, M.B.; Weisheit, A.; Barriobero-Vila, P.; Jägle, E.A.; Raabe, D. Massive nanoprecipitation in an Fe-19Ni-xAl maraging steel triggered by the intrinsic heat treatment during laser metal deposition. Acta Mater. 2017, 129, 52-60. [CrossRef]

25. Barriobero-Vila, P.; Gussone, J.; Stark, A.; Schell, N.; Haubrich, J.; Requena, G. Peritectic titanium alloys for 3D printing. Nat. Commun. 2018, 9, 3426. [CrossRef] [PubMed]

26. Wang, Y.M.; Voisin, T.; McKeown, J.T.; Ye, J.; Calta, N.P.; Li, Z.; Zeng, Z.; Zhang, Y.; Chen, W.; Roehling, T.T.; et al. Additively manufactured hierarchical stainless steels with high strength and ductility. Nat. Mater. 2017, 17, 63. [CrossRef] [PubMed]

27. Gong, H.; Rafi, K.; Gu, H.; Starr, T.; Stucker, B. Analysis of defect generation in Ti-6Al-4V parts made using powder bed fusion additive manufacturing processes. Addit. Manuf. 2014, 1-4, 87-98. [CrossRef]

28. Liu, Y.J.; Liu, Z.; Jiang, Y.; Wang, G.W.; Yang, Y.; Zhang, L.C. Gradient in microstructure and mechanical property of selective laser melted AlSi10Mg. J. Alloys Compd. 2018, 735, 1414-1421. [CrossRef]

29. Thijs, L.; Kempen, K.; Kruth, J.-P.; Van Humbeeck, J. Fine-structured aluminium products with controllable texture by selective laser melting of pre-alloyed AlSi10Mg powder. Acta Mater. 2013, 61, 1809-1819. [CrossRef]

30. Vrancken, B.; Thijs, L.; Kruth, J.P.; Van Humbeeck, J. Microstructure and mechanical properties of a novel $\beta$ titanium metallic composite by selective laser melting. Acta Mater. 2014, 68, 150-158. [CrossRef]

31. Prashanth, K.G.; Eckert, J. Formation of metastable cellular microstructures in selective laser melted alloys. J. Alloys Compd. 2017, 707, 27-34. [CrossRef]

32. Li, Y.; Gu, D. Parametric analysis of thermal behavior during selective laser melting additive manufacturing of aluminum alloy powder. Mater. Des. 2014, 63, 856-867. [CrossRef]

33. Li, W.; Li, S.; Liu, J.; Zhang, A.; Zhou, Y.; Wei, Q.; Yan, C.; Shi, Y. Effect of heat treatment on AlSi10Mg alloy fabricated by selective laser melting: Microstructure evolution, mechanical properties and fracture mechanism. Mater. Sci. Eng. A 2016, 663, 116-125. [CrossRef]

34. Men, H.; Fan, Z. Effects of solute content on grain refinement in an isothermal melt. Acta Mater. 2011, 59, 2704-2712. [CrossRef]

35. Piątkowski, J.; Przeliorz, R.; Gontarczyk, A. The Study of Phase Transformations of AlSi, $\mathrm{Cu}_{3}$ Alloy by DSC Method. Arch. Foundry Eng. 2016, 16, 109. [CrossRef]

36. Hurtalova, L.; Tillova, E.; Chalupova, M. The Structure Analysis of Secondary (Recycled) $\mathrm{AlSi}_{9} \mathrm{Cu}_{3} \mathrm{Cast}$ Alloy with and without Heat Treatment. Eng. Trans. 2013, 61, 197-218.

37. Backerud, L.; Chai, G.; Tamminen, J. Solidification Characteristics of Aluminum Alloys. Vol. 2. Foundry Alloys; American Foundrymen's Society, Inc.: Schaumburg, IL, USA, 1990.

38. Cho, J.-I.; Kim, C.-W. The Relationship between Dendrite Arm Spacing and Cooling Rate of Al-Si Casting Alloys in High Pressure Die Casting. Int. J. Metalcast. 2014, 8, 49-55. [CrossRef]

39. Hegde, S.; Prabhu, K.N. Modification of eutectic silicon in Al-Si alloys. J. Mater. Sci. 2008, 43, 3009-3027. [CrossRef]

40. Olson, G.B.; Bhadeshia, H.K.D.H.; Cohen, M. Coupled diffusional/displacive transformations: Part II. Solute trapping. Metall. Trans. A 1990, 21, 805-809. [CrossRef]

41. Fousova, M.; Dvorsky, D.; Vojtech, D. Additively manufactured aluminium AlSi10Mg alloy. Manuf. Technol. 2017, 17, 446-451.

42. Xu, W.; Brandt, M.; Sun, S.; Elambasseril, J.; Liu, Q.; Latham, K.; Xia, K.; Qian, M. Additive manufacturing of strong and ductile Ti-6Al-4V by selective laser melting via in situ martensite decomposition. Acta Mater. 2015, 85, 74-84. [CrossRef]

43. Brahmi, A.; Gerique, T.; Torralba, M.; Lieblich, M. Flow stress of rapidly solidified Al-5Cr-2Zr alloy as a function of processing variables. Scripta Mater. 1997, 37, 1623-1629. [CrossRef]

44. Mohanty, P.S.; Gruzleski, J.E. Grain refinement mechanisms of hypoeutectic Al-Si alloys. Acta Mater. 1996, 44, 3749-3760. [CrossRef]

45. Xu, C.; Xiao, W.; Hanada, S.; Yamagata, H.; Ma, C. The effect of scandium addition on microstructure and mechanical properties of Al-Si-Mg alloy: A multi-refinement modifier. Mater. Charact. 2015, 110, 160-169. [CrossRef] 
46. Srivastava, N.; Chaudhari, G.P.; Qian, M. Grain refinement of binary Al-Si, Al-Cu and Al-Ni alloys by ultrasonication. J. Mater. Process. Technol. 2017, 249, 367-378. [CrossRef]

47. Natori, K.; Utsunomiya, H.; Tanaka, T. Improvement in formability of semi-solid cast hypoeutectic Al-Si alloys by equal-channel angular pressing. J. Mater. Process. Technol. 2017, 240, 240-248. [CrossRef]

48. Tradowsky, U.; White, J.; Ward, R.M.; Read, N.; Reimers, W.; Attallah, M.M. Selective laser melting of AlSi10Mg: Influence of post-processing on the microstructural and tensile properties development. Mater. Des. 2016, 105, 212-222. [CrossRef]

C 2018 by the authors. Licensee MDPI, Basel, Switzerland. This article is an open access article distributed under the terms and conditions of the Creative Commons Attribution (CC BY) license (http://creativecommons.org/licenses/by/4.0/). 